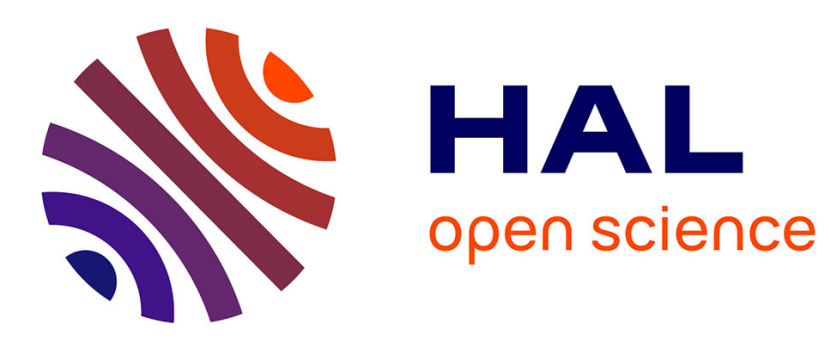

\title{
Market Discipline and Banking Supervision: The Role of Subordinated Debt
}

\author{
Isabelle Distinguin
}

\section{To cite this version:}

Isabelle Distinguin. Market Discipline and Banking Supervision: The Role of Subordinated Debt. 2008. hal-00916729

\section{HAL Id: hal-00916729 \\ https://hal-unilim.archives-ouvertes.fr/hal-00916729}

Preprint submitted on 10 Dec 2013

HAL is a multi-disciplinary open access archive for the deposit and dissemination of scientific research documents, whether they are published or not. The documents may come from teaching and research institutions in France or abroad, or from public or private research centers.
L'archive ouverte pluridisciplinaire HAL, est destinée au dépôt et à la diffusion de documents scientifiques de niveau recherche, publiés ou non, émanant des établissements d'enseignement et de recherche français ou étrangers, des laboratoires publics ou privés. 


\title{
Market discipline and banking supervision: the role of subordinated debt
}

\author{
Isabelle Distinguin $^{*}$ \\ University of Limoges, LAPE, 5 rue Félix Eboué BP3127, 87031 Limoges, France
}

February 2008

Preliminary version

\begin{abstract}
One of the aims of mandatory subordinated debt is to enhance both direct and indirect market discipline. Indeed, on the one hand, holding subordinated debt can affect banks' behaviour by changing their funding costs and, on the other hand, the rate of return of subordinated debt can be used by supervisors as a signal of their riskiness. In this paper, we analyse how subordinated debt may affect both bank riskiness and the effectiveness of bank supervision. We take into account the ability and incentives of subordinated debt holders to exercise market discipline. We show that requiring banks to hold subordinated debt should reduce bank risk and allow a better allocation of supervisory ressources. To do so, two criteria must be fulfilled: subordinated debt holders should have access to sufficient information about bank riskiness but they should not benefit from any kind of insurance.
\end{abstract}

Key words: Bank, Market Discipline, Bank Risk

JEL Classification: G21, G28

* tel : +33 (0)5 55149208 e-mail : isabelle.distinguin@unilim.fr 


\section{Introduction}

One of the aims of banking supervision is to early detect bank financial distress in order to avoid failure or to limit its cost. Supervisory risk assessment is mainly based on two procedures: off-site and on-site examinations. During on-site examinations, supervisors make an overall assessment of a banking institution in-situ which allows obtaining private information. They can check that the accounts of a bank provide a true and fair view of the bank's financial condition. This assessment is based on quantitative factors such as accounting data and on qualitative ones like management capabilities and internal control procedures. It leads to the assignment of supervisory ratings (like CAMELS ${ }^{1}$ ) and, if necessary, to the implementation of prompt corrective actions. However, supervisory resources are limited and on-site exams, which are the most efficient exams, are very costly. Thus, they are led only once a year except if problems are detected (Cole and Gunther, 1998). Between two on-site exams, supervisors lead off-site exams which rely exclusively on accounting data provided by banks on a quarterly basis. They enable supervisors to detect risky banks from quantitative data and to decide whether an early on-site exam must be conducted. However, accounting data are available only on an annual or quarterly basis and, between two onsite exams, their information content can decay fairly quickly (Gunther and Moore, 2003). Berger, Davies and Flannery [2000] show that the assessments of banks' financial conditions by supervisors are less accurate than the market ones except if supervisory assessments follow immediately an onsite exam ; in this case supervisory assessment is more accurate because they gain access to private information but it gets "stale" quite quickly. Between two on-site exams, the use of market information may improve supervisory risk assesment.

Indeed, market discipline can be exerted by market participants if they have sufficient information and if they have the incentives and ability to assess bank risk. BGFRS ${ }^{2}$ [1999] distinguishes two components in market discipline: direct and indirect market discipline. Direct market discipline means that market participants can directly influence banks' behaviour: uninsured debtholders are at risk and as they bear losses in case of bank failure they require a rate of return which increases with the risk they perceive. If they correctly assess banks' risk, the raise of the funding cost following an increase in risk should restrain banks' excessive risk taking. Indirect market discipline generates a signal about banks' risk which can be used by supervisors into banking supervision in order to better allocate supervisory ressources.

\footnotetext{
${ }^{1}$ Capital, Asset Quality, Management, Earnings, Liquidity and Sensitivity.

${ }^{2}$ Board Of Governors Of The Federal Reserve System (BGFRS)
} 
In the field of market discipline, a large part is dedicated to mandatory subordinated debt proposals. Several researchers suggest that banks should hold a portion of their liabilities into subordinated debt (see BGFRS, 1999 and Evanoff and Wall, 2000). Indeed, subordinated debt holders and supervisors are both concerned about bank risk. If a bank fails and if its assets value is less than its liabilities, depositors and senior debtholders are compensated first. Then, subordinated debt holders, who are junior claimholders, share the residual value. If a bank is at risk, subordinated debt holders bear a considerable risk because of their junior status. The aim of subordinated debt proposals is to enhance both direct and indirect market discipline: direct market discipline is exercised via the funding cost of banks which depends on bank risk, and indirect market discipline is possible if supervisors use subordinated debt rate of return as a signal about bank risk. Thus, market discipline may improve the efficiency of banking supervision and decrease its cost.

The aim of this paper is to determine how, between two on-site exams, mandatory subordinated debt can affect banks' behaviour and the effectiveness of banking supervision. To do so, we analyse the direct influence of subordinated debt on bank risk via funding cost. An indirect influence is also taken into account, supposing that supervisors use subordinated debt rate of return as a signal about bank risk. Indeed, between two on-site exams, supervisors watch banks and if a bank is viewed as particularly risky, they may decide to inspect it earlier and to implement corrective actions. As supervisors can not perfectly assess bank risk, the use of market assessment may allow a better allocation of supervisory ressources. However, the behaviour of subordinated debt holders is affected by the information they hold, their ability to use it and their perception of a possible bail out in case of bank failure. Thus, we consider several cases depending on the ability and incentives of subordinated debt holders to assess bank risk.

The paper is organized as follows. Section 2 presents the general framework of the model; we explain banks' excessive risk taking incentives and how we take into account banking supervision. In section 3, we introduce market discipline by requiring banks to hold a certain portion of their liabilities in subordinated debt. We analyse the effects depending on the ability and incentives of subordinated debt holders to exercise a dicipline. Two cases are considered: i) subordinated debt holders can not perfectly assess bank risk; ii) the perception of a possible bail out in case of bank failure affects their incentives to restrain banks' excessive risk taking. Finally, section 4 concludes. 


\section{General framework}

We consider a one-period model. A risk neutral bank is funded by debt. To simplify, we consider that there is no equity ${ }^{3}$. Total assets are normalized to 1 . The bank invests in a porfolio with a two-point distribution of the rate of return as in Gropp et Vesala [2004]:

$$
\begin{aligned}
& \mathrm{R}=\mathrm{R}_{\mathrm{H}} \text { with probability }(1-\rho)+m \rho \\
& \mathrm{R}=\mathrm{R}_{\mathrm{L}}=0 \text { with probability } \rho(1-m)
\end{aligned}
$$

$\rho$ is the probability of default in the absence of monitoring $(\rho \in[0,1])$ and $m$ represents the bank's choice of monitoring effort ( $m \in[0,1]$ ). Monitoring increases the probability that $\mathrm{R}_{\mathrm{H}}$ is obtained but it is costly. We assume a strictly positive and convex monitoring cost schedule $\mathrm{C}(\mathrm{m})\left(\mathrm{C}^{\prime}(\mathrm{m})>0\right.$, $\mathrm{C}^{\prime \prime}(\mathrm{m})>0$ et $\left.\mathrm{C}(0)=0\right)$.

The probability of default depends on an exogenous parameter $\rho$ and on the monitoring effort of the bank. If the bank chooses an effort of monitoring equal to 1 , it receives the rate of return $\mathrm{R}_{\mathrm{H}}$ with certainty. If $\mathrm{R}=0$, the bank cannot pay off its debt and fails. Thus, the probability of default is $\rho(1-m)$. Bank risk, taken into account via the probability of default, depends on two components: i) the effort of monitoring chosen, $m$, non observable; ii) the probability of default in absence of monitoring, $\rho$, which can be interpreted as the observable part of the bank's asset risk.

As $\rho$ is exogenous, when the bank chooses its level of monitoring $m$ it also determines its risk of default. Thus, we will consider that an increase in monitoring is identical to a decrease in bank risk of default.

First, we consider that debt is fully insured. Its amount is normalized to 1 . We assume that the insurance premium cannot be made contingent on bank risk and for simplicity it is set equal to

\footnotetext{
${ }^{3}$ Our aim is to study the link between banking supervision and market discipline (pillars 2 and 3 of Basel II) taking into account the conditions of effectiveness of market discipline. To simplify, we do not consider equity even if we are aware of the link between equity and subordinated debt via, for example, the capital constraint. Besides, the subordinated debt rate of return should depend on the capital cushion held by the bank, which influences its default probability. Here, this rate of return depends on the probability of failure but it is independent of the capital, which is normalized to 0 , and depends solely on the choice of monitoring and on an exogenous parameter. This is taken into account, in this model, by a two-point distribution of the rate of return.
} 
zero. Depositors are fully insured, and they earn the risk free rate $\left(\mathrm{R}_{\mathrm{f}}\right)$ on their deposits even if the bank fails.

\subsection{First best}

From a social perspective, the level of monitoring chosen by the bank should be such that it maximizes the expected return of bank's assets, net of the monitoring cost and of the cost of debt taken into account whether the bank fails or not. Thus, the expected value VS is maximized:

$$
\text { (1) } \max _{m} V S=[(1-\rho)+m \rho]\left(R_{H}-R_{f}\right)-\rho(1-m) R_{f}-C(m)
$$

VS is maximized when:

$$
\text { (2) } \rho R_{H}=C_{m}^{\prime}
$$

The expected cost of $\mathrm{debt}^{4}$ does not depend on the level of monitoring, $m$, and is equal to $\mathrm{R}_{\mathrm{f}}$. Equation (2) indicates that, at the equilibrium, the marginal return of monitoring is equal to its marginal cost. The marginal return corresponds to the increase in the non default probability, due to the increase in monitoring, multiplied by bank's earnings in the non default state. We note $m^{S}$ the level of monitoring corresponding to this situation.

\subsection{Bank's excessive risk taking}

We now consider the maximization problem from an individual bank point of view. We will show that the bank takes too much risk that is chooses a level of monitoring less than the socially optimal one.

As the bank has limited liabilities, it does not have to pay off depositors in case of default. Therefore the bank only considers the non default state into its optimization problem and it chooses the level of monitoring such as to maximize its expected value:

${ }^{4}[(1-\rho)+m \rho] R_{f}+\rho(1-m) R_{f}=R_{f}$ 
(3) $\max _{m} V=[(1-\rho)+m \rho]\left(R_{H}-R_{f}\right)+\rho(1-m)(0)-C(m)$

The problem can be rewritten:

(4) $\max _{m} V=[(1-\rho)+m \rho] R_{H}-R_{f}+\rho(1-m) R_{f}-C(m)$

The term $\rho(1-m) R_{f}$ represents the amount the bank does not have to pay in case of default because of its limited liabilities. Besides, as deposits are fully insured, depositors know that they will be refunded even if the bank fails and therefore they are not penalized if the bank takes excessive risk. The rate of return on deposits is independent of bank's risk of default. Thus, the expected cost of debt, which is the cost of debt times the non default probability $\left([(1-\rho)+m \rho] R_{f}\right)$, is an increasing function of the level of monitoring chosen by the bank (it decreases with its default risk).

The expected value of the bank is maximized when:

(5) $\rho\left(R_{H}-R_{f}\right)=C_{m}^{\prime}$

An increase in monitoring raises the probability for the bank to pay the cost of the debt. Thus, the return of monitoring is less than the one previously obtained. As we assume a strictly positive and convex monitoring cost schedule, we can conclude that the level of monitoring chosen by the bank $\left(m^{B}\right)$ is less than the socially optimal one $\left(m^{S}\right)$. 


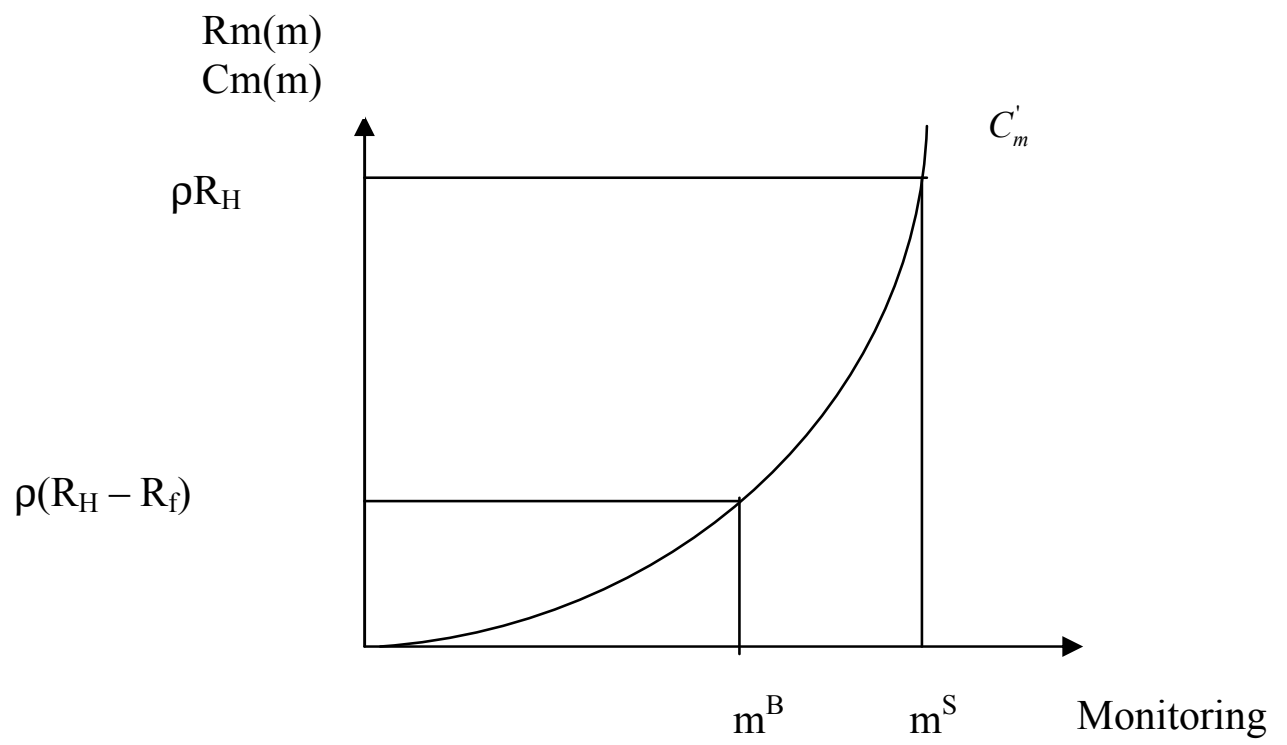

Figure 1: the socially optimal level of monitoring $\left(\mathrm{m}^{\mathrm{S}}\right)$ and the level of monitoring chosen by the bank $\left(\mathrm{m}^{\mathrm{B}}\right)$

If the debt is fully insured, the bank chooses an excessive level of risk (i.e. a low level of monitoring) because the expected cost of its liabilities $\left((1-\rho+m \rho) R_{f}\right)$ is a decreasing function of default risk (increasing function of monitoring).

From a social point of view, the level of monitoring should be higher because the cost of liabilities in case of default has to be taken into account in the optimization problem. This excessive risk, due to the fact that insured deposit cost is independent of risk, has been emphasized in several models (Blum [2002] and Levonian [2001]).

\subsection{Banking supervision}

We now introduce supervision. In this model, supervisors aim to control the risk taken by the bank.

Park [1997] considers, in his model, the impact of supervision on bank's behaviour when supervisors have limited resources and thus cannot closely monitor each bank. Supervisors use the information available (the level of capitalization and the proportion of the bank's assets invested in the risky project) to classify banks into two groups: safe and risky. Regulators order corrective 
actions and closely supervise risky banks. Thus, banks cannot have a positive option value ${ }^{5}$ and they take it into account in their optimization problem. Choice variables in Park [1997], which are the level of capitalization and the proportion of the bank's assets invested in the risky project, are affected by the fact that supervisors use them explicitly to decide the implementation of corrective actions. Unlike the case without regulation, banks do not choose to take the maximum risk.

Here, we suppose that supervisors classify, between two on-site exams, banks into two groups depending on their estimated risk of default. They decide to early inspect a bank if its probability of default is greater than a threshold they fixed. However, between two on-site exams, the risk of the bank is not fully observable. To assess it, supervisors use statistical models relying on accounting information ${ }^{6}$ which is essentially backward looking. Thus it does not reflect perfectly the current situation of the bank. Besides, these statistical models are rigid and they cannot be adjusted as frequently as necessary. Therefore, supervisors assess imperfectly the risk taken by the bank. To take into account this imperfection, we suppose that supervisors know the observable assets risk, $\rho$, but not the level of monitoring chosen by the bank. As a consequence, supervisory resources are not optimally allocated because of classification errors, which imply that particularly risky banks may not be inspected whereas safe banks may be subjected to inspection. At the bank level, the probability of being inspected does not depend on the true level of monitoring but on the level assessed by supervisors. However, we suppose that after an inspection, supervisors are fully informed about the situation of the bank and they can impose corrective actions such as to limit the risk taken by the bank. These measures depend on the situation of the bank: only few changes are required if the financial situation of the bank is correct but supervisors are all the more demanding than the situation of the bank is damaged.

Corrective actions implemented after an on-site exam can be recommendations on decisions to take to improve the quality of management or the financial situation, or some restrictions into

\footnotetext{
${ }^{5}$ This option value is due to the limited liabilities of the bank. It is the failure probability times the expected deficiency of assets (liability - assets) when the bank fails.

${ }^{6}$ These models are used to anticipate financial distress (prediction of bank failures or downgradings) and correspond for example to the American systems SEER (System for Estimating Examination Ratings) and SCOR (Statistical CAMELS Offsite Rating) or to the French system SAABA (Support System for Banking Analysis). Recently, some systems have included market information in addition to accounting information. The central bank of Sweden uses equity market information via indicators such as the variation of the "distance to default" or the EDF (Expected Default Frequency) (Persson et Blavarg, 2003).
} 
banks' activities. Supervisors can also enforce sanctions in the form of financial fines, official warnings or in extreme cases accreditation withdraws.

Here, to take into account the consequences of these measures on the behaviour of the bank, corrective actions are modelized as a cost CC borne by the bank, as soon as it is inspected. This cost is defined such that it eliminates excessive risk taking incentives from a social point of view: if a bank is inspected it chooses the optimal level of monitoring. Thus, the expected cost of liabilities and corrective actions is independent of risk:

(6) $[(1-\rho)+m \rho] R_{f}+C C=R_{f}$

That is:

(7) $C C=\rho(1-m) R_{f}$

The cost of corrective actions borne by an inspected bank is a decreasing function of the level of monitoring exerted by the bank. It is a function of the level of monitoring because it is determined after the inspection when supervisors have all the information necessary to correctly assess the risk of the bank. Thus, the existence of these measures encourages the bank to restrict its risk.

The bank maximizes its expected value taking into account the possibility of being inspected and of bearing corrective actions:

(8) $\max _{m} V=[(1-\rho)+m \rho]\left(R_{H}-R_{f}\right)-q C C-C(m)$

with $C C=\rho(1-m) R_{f}$

with $\mathrm{q}$ the inspection probability which is independent of the true level of monitoring as it is unknown before the inspection.

Incorporating $\mathrm{CC}$ into the objective function, the problem of the bank is: 
(9) $\max _{m} V=[(1-\rho)+m \rho] R_{H}-R_{f}+(1-q) \rho(1-m) R_{f}-C(m)$

The term $\rho(1-m) R_{f}$ corresponds to the saving made by the bank on its payment to depositors in case it defaults because of its limited liabilities. However, this saving is possible only if the bank is not inspected that is with a probability $1-q$.

The expected value of the bank is maximized when:

$$
\rho\left(R_{H}-(1-q) R_{f}\right)=C_{m}^{\prime}
$$

Thus, the probability of being inspected encourages the bank to choose a level of monitoring $\left(m^{I N S P}\right)$ greater than the one chosen without supervision $\left(\mathrm{m}^{B}\right)$ because the expected saving on the cost of liabilities in case of default, which encourages to reduce monitoring, exists only if the bank is not inspected. If all banks were inspected with certainty ( $q=1)$, the optimal level of monitoring from a social point of view $\left(\mathrm{m}^{S}\right)$ would be reached. However, as supervisors have only limited resources, they do not inspect all banks and, as they have only imperfect information about banks' risk, they cannot discriminate between banks to inspect according to their risk.

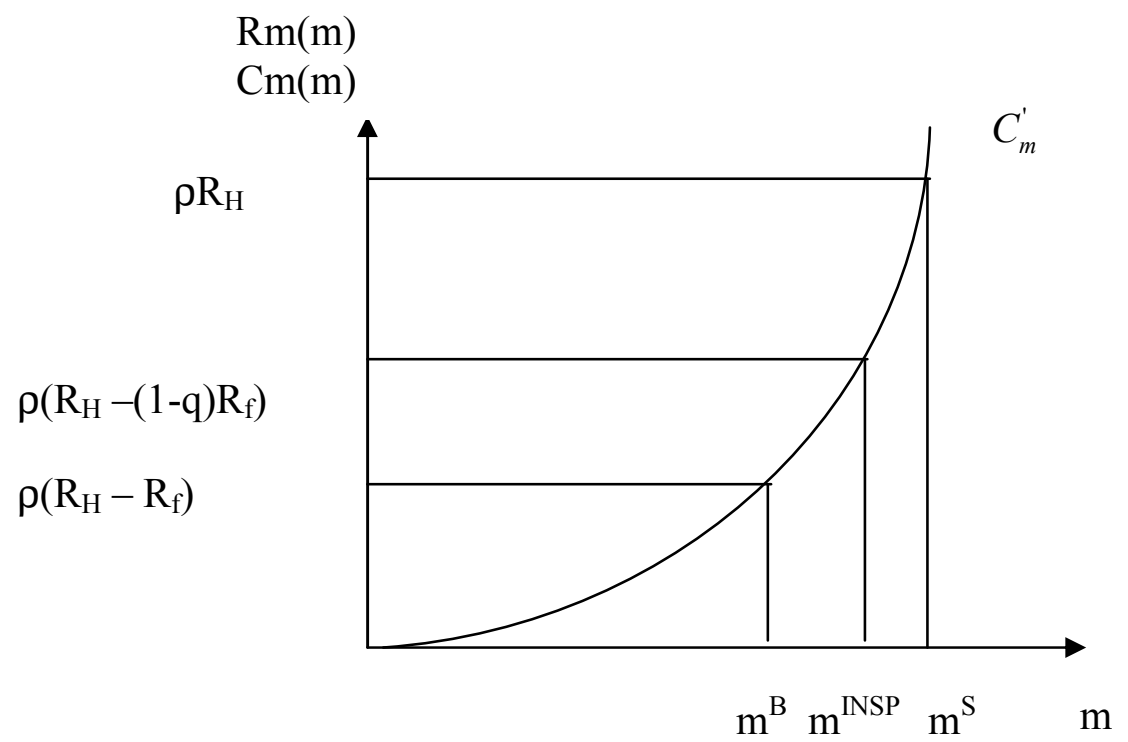

Figure 2: socially optimal level of monitoring $\left(\mathrm{m}^{\mathrm{s}}\right)$, level of monitoring chosen by the bank in absence of banking supervision $\left(\mathrm{m}^{\mathrm{B}}\right)$ and level of monitoring chosen by the bank subjected to banking supervision ( $\mathrm{m}^{\mathrm{INSP}}$ ) 
Between two on-site exams, supervision allows a reduction in bank's excessive risk. However, as supervisors have only imperfect information about the risk of default of the bank, the allocation of supervisory resources is not optimal and the probability of an inspection is independent of the actual monitoring.

In order to improve excessive risk taking limitation, the use of market discipline can be considered via, for example, mandatory subordinated debt which implies that banks have to hold a certain portion of their liabilities into subordinated debt. The effectiveness of bank supervision may be improved thanks to direct and indirect market discipline induced by these liabilities. Indeed, as their rate of return depends on bank's risk of default, it should affect bank's behaviour and could be used by supervisors as a signal about bank's risk ${ }^{7}$. The improvement of the effectiveness of bank supervision is possible if the market can assess bank's situation and help identifying or controlling its risk exposure. Indeed, if supervisors benefit from private information thanks to on-site exams, this information is updated at a low frequency in contrast to market information which is available on a daily basis. Besides, because banks' financial assessment models on which rely supervisors are rigid, they cannot adjust continuously in contrast to market information. Requiring banks to hold a certain portion of their liabilities into subordinated debt may allow a better control of bank risk. However, depending on the ability and incentives of subordinated debt holders to exercise market discipline, bank's risk taking and the effectiveness of bank supervision can be modified quite differently.

\section{Market discipline: a complement to banking supervision}

Until this section, we have considered a bank fully funded with deposits. Depositors are fully insured and thus indifferent to the default risk of the bank. Yet, other actors can exist: subordinated debt holders. They are concerned about bank's risk of default because, as they are not insured, they are not compensated in case of the bank defaults.

Now the bank has to hold a portion, $\mathrm{u} \in[0,1]$, of their liabilities into subordinated debt. Bank's liabilities are subdivided into two parts: insured deposits in proportion (1-u) and subordinated debt in proportion $\mathrm{u}$ with $\mathrm{u}$ exogenous.

\footnotetext{
${ }^{7}$ See BGFRS [1999].
} 
Bank's behaviour is affected by the presence of subordinated debt because market discipline can be exerted by its holders. This discipline is exerted via two channels: a direct channel, which corresponds to the direct influence of the market on bank's behaviour, and an indirect channel corresponding to the fact that supervisors use the assessment of bank's risk made by the market.

Blum [2002] shows that the level of risk chosen by the bank corresponds to the socially optimal one if subordinated debt holders can perfectly observe bank's risk, if debt is fully uninsured, if there is no bankruptcy cost borne by the bank and if the bank can commit to a level of risk. When only a portion of debt is uninsured, the presence of resources with a cost depending on bank's risk enables to get closer to the socially optimal solution. We find the same result in this model (see appendix).

However, on top of this direct market discipline considered in Blum [2002], we take into account an indirect market discipline: supervisors use market information to assess bank's risk of default and to decide to lead early on-site inspections. This indirect market discipline is pertinent, even if subordinated debt holders are fully informed about bank's risk, once a portion of debt is insured because bank's risk remains greater than the socially optimal level. Indeed, as underlined by Levonian [2001], "the subordinated debt market does "punish" shareholders for shifting risk to debt holders, which is the essence of market discipline. But because subordinated debt is just that subordinate, and therefore junior to deposits - the subordinated debt holders in effect "give credit" to shareholders for the portion of risk shifted past them to the senior claimant (or any deposit guarantor)". Market discipline is exerted only for the portion of debt which is uninsured. Once a portion of debt is insured, the bank has incentives to take excessive risk.

We also consider the conditions of effectiveness of market discipline. Indeed, it is likely that the assessment of bank's risk by subordinated debt holders is not perfect. And, market discipline is effective only if debt holders have the abilities and incentives to exercise it. The ability of market participants to assess bank's risk depends on the information they hold and on their ability to analyze it, their incentives depend on the credibility of non bail out in case of bank's default. Thus, we consider the consequences of mandatory subordinated debt in different contexts. We first consider that subordinated debt holders cannot perfectly assess bank's risk. Then, we consider that subordinated debt holders can perfectly assess bank's risk but perceive the possibility of a bail out in case of bank's default. 
We suppose that subordinated debt holders assess only imperfectly the risk of the bank. With a probability $\alpha \in[0 ; 1]^{8}$, they correctly assess the level of monitoring of the bank and they adjust the rate of return they ask for. With probability (1- $\alpha)$, they cannot correctly assess monitoring. The parameter $\alpha$ reflects the information held by the market and its ability and rapidity to analyze it, to extract actual risk from it and to incorporate it into the rate of return they require. If $\alpha=0$, subordinated debt holders cannot assess actual monitoring and there is no market discipline. If $\alpha=1$, market discipline is perfect, the rate of return required by subordinated debt holders perfectly reflects bank's risk of default. Between these two extremes, subordinated debt holders can partially assess actual monitoring and the rapidity and effectiveness with which they incorporate it into the rate of return they ask for are represented by the parameter $\alpha$.

We suppose that subordinated debt holders accept an expected rate of return equal to the risk free rate of return? ${ }^{9}$.

If $\alpha=1$, they perfectly assess actual monitoring and the rate of return of subordinated debt is:

$$
R_{u}^{I}=\frac{R_{f}}{[(1-\rho)+m \rho]}
$$

If $\alpha=0$, they cannot correctly estimate the level of monitoring chosen by the bank. The rate of return of subordinated debt is independent of $m$ but depends on the observable risk ( $\rho$ ) and on an average level of monitoring, $\tilde{m}$, depending on past information about the whole banking sector :

$$
R_{u}^{N I}=\frac{R_{f}}{[(1-\rho)+\tilde{m} \rho]}
$$

\footnotetext{
${ }^{8}$ This notion of partial observability is used by Boot and Schmeits [2000]. They study the potential benefits of conglomerate depending on market discipline.

9 This hypothesis used by Calem and Rob [1999] and Blum [2002] implies that subordinated debt holders are risk neutral. If we consider that they are risk adverse, it implies that they ask for a risk premium. In this case, the expected rate of return is equal to the risk free rate plus this premium. In this model, it would modify the equilibrium value of the level of monitoring without changing our conclusions.
} 
Thus, the rate of return of subordinated debt is:

$$
R_{u}^{I M P I N F}=\alpha \frac{R_{f}}{[(1-\rho)+m \rho]}+(1-\alpha) \frac{R_{f}}{[(1-\rho)+\tilde{m} \rho]}
$$

Once $\alpha \neq 1$, it reflects bank's actual risk of default only imperfectly. The error in risk assessment is all the higher as the ability of subordinated debt holders to correctly assess bank's risk and to incorporate it into the rate of return they ask for is low (ie $\alpha$ low).

We aim to determine the consequences of the imperfect assessment of bank's risk by the market on bank's behaviour and on the effectiveness of supervision. First, we only consider direct market discipline: the bank has to hold a portion $u$ of its liabilities into subordinated debt but the probability of an inspection is independent of the subordinated debt rate of return. Then, we add indirect market discipline by supposing that supervisors use market information to classify banks.

\subsubsection{Direct market discipline}

We wonder how mandatory subordinated debt affects bank's behaviour and how the imperfection of bank's risk assessment by the market can modify the risk taken by the bank.

With a portion $u$ of subordinated debt, the problem of the bank is:

$$
\begin{aligned}
& \max _{m} V=[(1-\rho)+m \rho]\left(R_{H}-(1-u) R_{f}-u R_{u}^{I M P I N F}\right)-q C C^{I M P I N F}-C(m) \\
& \text { with }: R_{u}^{I M P I N F}=\alpha \frac{R_{f}}{[(1-\rho)+m \rho]}+(1-\alpha) \frac{R_{f}}{[(1-\rho)+\tilde{m} \rho]}
\end{aligned}
$$

The bank is inspected with probability q and is subject to correctives actions. We consider that these measures are such that when they are imposed they remove excessive risk taking. This is taken into account via the cost $C C^{\mathrm{IMPINF}}$. Without these measures, the expected cost of debt is $u \alpha \mathrm{R}_{\mathrm{f}}+(1-\rho$ $+\mathrm{m} \rho)\left[(1-\mathrm{u}) \mathrm{R}_{\mathrm{f}}+\mathrm{u}(1-\alpha) R_{u}^{N I}\right]$ and is increasing with monitoring. The cost implied by corrective actions is fixed so that the expected cost of debt and corrective actions becomes independent of monitoring: 


$$
[(1-\rho)+m \rho]\left[(1-u) R_{f}+u(1-\alpha) R_{u}^{N I}\right]+C C^{I M P I N F}=(1-u) R_{f}+u(1-\alpha) R_{u}^{N I}
$$

That is :

$$
C C^{I M P I N F}=\rho(1-m)\left((1-u) R_{f}+u(1-\alpha) R_{u}^{N I}\right)
$$

The problem can be rewritten:

$$
\max _{m} V=[(1-\rho)+m \rho] R_{H}-(1-u+u \alpha) R_{f}-u(1-\alpha) R_{u}^{N I}+(1-q) \rho(1-m)\left((1-u) R_{f}+u(1-\alpha) R_{u}^{N I}\right)-C(m)
$$

Excessive risk taking incentives still exist with probability (1-q) for the portion of debt insured (1-u) and the portion $(1-\alpha)$ of the uninsured debt.

The expected value of the bank is maximized when:

$$
\rho\left[R_{H}-(1-q)\left((1-u) R_{f}+u(1-\alpha) R_{u}^{N I}\right)\right]=C_{m}^{\prime}
$$

By comparing (10) and (18), we can notice that the presence of subordinated debt leads to a greater level of monitoring and so a lower default probability only if:

$$
\alpha>1-\frac{R_{f}}{R_{u}^{N I}}
$$

Subordinated debt holders must have access to valuable and adequate information and they must have the ability to correctly assess bank's risk of default and to incorporate it into the rate of return they require. It means, here, that $\alpha$ must be sufficiently high. If it is not the case, bank's risk of default is increased in presence of subordinated debt. The presence of subordinated debt modifies bank's choice of monitoring. Indeed, with probability $\alpha$, the rate of return correctly incorporates bank's risk of default, the bank has no incentives to increase its risk because it is fully reflected in subordinated debt rate of return. By contrast, with probability $(1-\alpha)$, the rate of return is 
independent of bank's risk and is greater than the risk free rate. Thus, by decreasing its monitoring, the bank increases its default probability and so decreases the probability of having to pay this higher rate.

Depending on the information held by subordinated debt holders and their ability to use it, the presence of subordinated debt contributes either to limit bank's risk of default or to increase it.

\subsubsection{The use of market information by supervisors}

We now consider the effects of indirect market discipline in addition to the direct consequences of the presence of subordinated debt on bank's behaviour. The probability of an inspection depends on the rate of return of subordinated debt. Supervisors use market assessment about bank's risk of defaultyto classify banks and to decide whether to early inspect a bank. They infer the probability of default of the bank estimated by the market from the rate of return of subordinated debt and they decide to early inspect a bank if its probability is greater than the threshold they fixed. Thus, the probability for a bank of being inspected is now a function of its monitoring. Indeed, we suppose that, between two on-site exams, the assessment of bank's risk by the market is better than supervisors' assessment. This hypothesis, empirically checked by Berger, Davies et Flannery [2000], is justified by the fact that market's assessment is more forward looking and more frequent and methods used can adjust continuously contrary to the fixed methods used by supervisors.

The cost of supervision errors borne when supervisors use market information is lower than the one obtained using only the information held by supervisors. The reason is that, with probability $(1-\alpha)$, like supervisors, subordinated debt holders does not know the actual monitoring of the bank but, with a probability $(1-\alpha)$, they can perfectly assess it. The use of market information, even if it is imperfect, by limiting bank's risk assessment errors, enables a better allocation of supervisory resources and limits the cost of errors. The use of this information is all the more beneficial as the ability of the market to correctly assess bank's risk of default $(\alpha)$ is high.

The behaviour of the bank is also affected by indirect discipline, its problem becomes: 
(20)

$$
\begin{aligned}
& \max _{m} V=[(1-\rho)+m \rho]\left(R_{H}-(1-u) R_{f}-u R_{u}^{I M P I N F}\right)-q C C^{I M P I N F}-C(m) \\
& \text { with: } R_{u}^{I M P I N F}=\alpha \frac{R_{f}}{[(1-\rho)+m \rho]}+(1-\alpha) R_{u}^{N I} \\
& C C^{I M P I N F}=\rho(1-m)\left((1-u) R_{f}+u(1-\alpha) R_{u}^{N I}\right) \\
& \mathrm{q}=\mathrm{q}\left(R_{u}^{\text {IMPINF }}\right) \text { and } \mathrm{q}^{\prime}\left(R_{u}^{\text {IMPINF }}\right)>0
\end{aligned}
$$

The probability of being inspected $(q)$ is an increasing function of subordinated debt rate of return which is a decreasing function of bank monitoring.

The problem can be rewritten:

$$
\max _{m} V=[(1-\rho)+m \rho] R_{H}-(1-u+u \alpha) R_{f}-u(1-\alpha) R_{u}^{N I}+(1-q) \rho(1-m)\left((1-u) R_{f}+u(1-\alpha) R_{u}^{N I}\right)-C(m)
$$

The expected value of the bank is maximized when:

$$
\rho\left[R_{H}-(1-q)\left((1-u) R_{f}+u(1-\alpha) R_{u}^{N I}\right)-q_{m}^{\prime}(1-m)\left((1-u) R_{f}+u(1-\alpha) R_{u}^{N I}\right)\right]=C_{m}^{\prime}
$$

By using market information, supervisors make the probability of an inspection function of bank's actual monitoring. Thus, comparing to the previous situation where supervisors does not use market information, the bank can influence its probability of being inspected: it diminishes when the bank increases its monitoring. This is reflected into the marginal return of monitoring.

Thus, if the bank holds subordinated debt, it has incentives to increase its monitoring if subordinated debt holders can assess its risk with a sufficient accuracy. They exercise a direct market discipline which allows a decrease in bank's default probability. By contrast, if their assessment of bank's risk is not sufficiently accurate, the presence of subordinated debt leads bank to choose a lower level of monitoring.

Inspection of banks by supervisors enables, in all cases, a decrease in bank's risk of default. However, as they have only limited resources, they cannot inspect all banks and, due to a lack of information, they cannot discriminate between banks according to their default probability. They 
make errors which are costly. If they decide to use market information included into subordinated debt rate of return, supervisors can reduce theirs errors and allocate their resources more efficiently. Besides, by using market information, they make the probability of inspection, via subordinated debt rate of return, dependent on the level of monitoring decided by the bank.

\subsection{Credibility of the absence of bail out in case of bank's default}

We now consider the incentives of subordinated debt holders to exercise market discipline. We aim to determine how bank's risk of default and the effectiveness of supervision vary depending on these incentives. We suppose that subordinated debt holders can perfectly assess bank's risk of default however they perceive the possibility to receive an indemnity in case of bank's default: supervisors are not credible in the limitation of insurance to depositors. The probability perceived by the market of a bail out in case of bank's default is $\gamma \in[0,1]$. This absence of credibility in the limitation of insurance can be considered in the case of large banks perceived by the market as too big to fail and for which a lender of last resort can intervene in case of distress.

With probability $\gamma$, subordinated debt holders suppose that in case of bank's default they will be compensated. Besides, they ask for an expected rate of return equal to the risk free rate. Thus, the expected return of subordinated debt holders is:

$$
E\left(R_{u}\right)=[(1-\rho)+m \rho] R_{u}^{\gamma}+\rho(1-m) \gamma R_{u}^{\gamma}=R_{f}
$$

And, the rate of return they require is:

$$
R_{u}^{\gamma}=\frac{R_{f}}{[(1-\rho)+m \rho]+\rho(1-m) \gamma}=\frac{R_{f}}{1-(1-\gamma) \rho+m \rho(1-\gamma)}
$$

If the perceived probability of being compensated is equal to zero, we find $R_{u}^{\gamma}=\frac{R_{f}}{[(1-\rho)+m \rho]}$. On the other hand, if this probability is equal to one, which means that subordinated debt holders are convinced that they will be compensated if the bank defaults, the rate of return is equal to the risk free rate. The perception of a possible extension of the compensation to the whole creditors 
diminishes the rate of return they ask for. The rate of return of subordinated debt reflects only imperfectly bank's risk of default.

We aim to determine the impact of the degree of supervisors' credibility to not compensate subordinated debt holders on bank's behaviour and on the effectiveness of supervision. First, we consider direct market discipline: banks have to hold a portion u of their liabilities into subordinated debt but their probability of being inspected is independent of subordinated debt rate of return. Then, we add indirect market discipline by supposing that supervisors use market information to classify banks.

\subsubsection{Direct market discipline}

We consider the consequences of the perception of an implicit insurance by subordinated debt holders on bank's choice of monitoring.

With a portion $\mathrm{u}$ of subordinated debt, the problem of the bank is:

$$
\begin{aligned}
& \max _{m} V=[(1-\rho)+m \rho]\left(R_{H}-(1-u) R_{f}-u R_{u}^{\gamma}\right)-q C C^{\gamma}-C(m) \\
& \text { with }: R_{u}^{\gamma}=\frac{R_{f}}{1-(1-\gamma) \rho+m \rho(1-\gamma)}
\end{aligned}
$$

The cost of corrective actions, imposed with a probability q independent of the level of monitoring, is determined so that it eliminates excessive risk taking. Subordinated debt rate of return does not perfectly reflect the risk of the bank due to the lack of credibility of the restriction of insurance to depositors. We can write the rate of return $R_{u}^{\gamma}$ as:

$$
R_{u}^{\gamma}=\frac{R_{f}}{(1-\rho)+m \rho}-\frac{R_{f} \gamma \rho(1-m)}{[(1-\rho)+m \rho][((1-\rho)+m \rho)+\gamma \rho(1-m)]}
$$

This rate of return is less than the one that would reflect the actual default risk of the bank, because of the second term which takes into account the perception of subordinated debt holders to 
be compensated in case the bank defaults. Thus, the expected cost of subordinated debt $\left(R_{f}-\frac{R_{f} \gamma \rho(1-m)}{[((1-\rho)+m \rho)+\gamma \rho(1-m)]}\right)$ is an increasing function of the level of monitoring ${ }^{10}$.

As corrective actions eliminate excessive risk taking, we set the cost of these measures so that the expected cost of debt and corrective actions is independent of bank monitoring:

$$
[(1-\rho)+m \rho]\left((1-u) R_{f}+u R_{u}^{\gamma}\right)+C C^{\gamma}=R_{f}
$$

That is:

$$
C C^{\gamma}=\rho(1-m)(1-u) R_{f}+u R_{f}-[(1-\rho)+m \rho] u R_{u}^{\gamma}
$$

The problem of the bank can be rewritten as:

$$
\begin{aligned}
& \max _{m} V=[(1-\rho)+m \rho] R_{H}-(1-u) R_{f}-q u R_{f}+(1-q)\left(\rho(1-m)(1-u) R_{f}-[(1-\rho)+m \rho] u R_{u}^{\gamma}\right) \\
& -C(m)
\end{aligned}
$$

The expected value of the bank is maximized when:

$$
\rho R_{H}-(1-q)\left(\rho\left((1-u) R_{f}+u R_{u}^{\gamma}\right)+[(1-\rho)+m \rho] u\left(R_{u}^{\gamma}\right)_{m}^{\prime}\right)=C_{m}^{\prime}
$$

The presence of subordinated debt with its holders perceiving the possibility of a compensation if the bank defaults, has two opposite effects on the marginal return of monitoring. Comparing with the case without subordinated debt:

- It decreases because the cost of debt in case of non default is greater $\left((1-\mathrm{u}) \mathrm{R}_{\mathrm{f}}+\mathrm{u} R_{u}^{\gamma}>\mathrm{R}_{\mathrm{f}}\right)$ and an increase in monitoring raises the probability of having to pay this higher cost,

${ }^{10}\left[E\left(R_{u}\right)\right]_{m}^{\prime}=\frac{\rho \gamma R_{f}}{[((1-\rho)+m \rho)+\gamma \rho(1-m)]^{2}}>0$ 
- It increases because the rate of return of subordinated debt, paid in case of non default, is a decreasing function of the monitoring decided by the bank $\left(\left(R_{u}^{\gamma}\right)_{m}^{\prime}<0\right)$.

By comparing (10) and (30), we can determine when mandatory subordinated debt leads to a greater level of monitoring and thus to a lower probability of default. We find that the probability of default is lower compared to the one obtained without subordinated debt if:

$$
(1-q)\left(\rho\left((1-u) R_{f}+u R_{u}^{\gamma}\right)+[(1-\rho)+m \rho] u\left(R_{u}^{\gamma}\right)_{m}^{\prime}\right)<\rho(1-q) R_{f}
$$

That is:

$$
\rho\left(R_{u}^{\gamma}-R_{f}\right)+[(1-\rho)+m \rho]\left(R_{u}^{\gamma}\right)_{m}^{\prime}<0
$$

Thus, the probability of default is lower when the bank holds subordinated debt if:

$$
\gamma<\frac{1-2 \rho(1-m)+[\rho(1-m)]^{2}}{[\rho(1-m)]^{2}}
$$

The perception by subordinated debt holders of a possible compensation if the bank defaults must be sufficiently low so that the presence of subordinated debt leads to a decrease in the probability of default of the bank via direct market discipline.

\subsubsection{Use of market information by supervisors}

We consider the effects of indirect market discipline in addition to direct discipline: the probability of being inspected depends on the rate of return of subordinated debt.

Once $\gamma \neq 0$, the perception of a possible compensation in case of the bank defaults is equivalent to an overestimation of bank monitoring. Subordinated debt rate of return, which is used by supervisors as a signal about bank's default risk, is: 


$$
R_{u}^{\gamma}=\frac{R_{f}}{[(1-\rho)+m \rho]+\rho(1-m) \gamma}=\frac{R_{f}}{[(1-\rho)+\hat{m} \rho]}
$$

The signal carried by the market overestimates the actual level of monitoring. Supervisors infer from $R_{u}^{\gamma}$ that subordinated debt holders assess a level of monitoring $\hat{m}$ :

$$
\hat{m}=m+\gamma(1-m)>m
$$

The bias introduced in the market signal due to the lack of credibility of subordinated debt holders' non insurance implies that the probability of default inferred from market information is always lower than the true one. Thus, it is not possible on the basis of this information to inspect a bank which is in reality safe. On the other hand, it is possible that the market signal leads supervisors not to inspect a risky bank. Errors of non inspection can be larger if supervisors use market information and this is all the more likely as the perception of a compensation in case of bank's default $(\gamma)$ is high.

If subordinated debt holders think that they will be compensated if the bank defaults, for example if they perceive the bank as too big to fail, they have no incentives to assess bank's risk of default and to incorporate it into the rate of return they ask for. This rate reflects only partially bank's risk. Thus, the use of market information by supervisors does not always reduce errors in supervision. The allocation of supervisory resources is not necessarily more efficient by using market information.

The problem of the bank is also affected by the use of market information, it becomes:

$$
\begin{aligned}
& \left.\underset{m}{\max V}=[(1-\rho)+m \rho] R_{H}-(1-u) R_{f}-u R_{u}^{\gamma}+\rho(1-m)\left((1-u) R_{f}+u R_{u}^{\gamma}\right)\right)-q C C^{\gamma}-C(m) \\
& \text { with: } R_{u}^{\gamma}=\frac{R_{f}}{1-(1-\gamma) \rho+m \rho(1-\gamma)} \\
& C C^{\gamma}=\rho(1-m)(1-u) R_{f}+u R_{f}-[(1-\rho)+m \rho] u R_{u}^{\gamma} \\
& \mathrm{q}=\mathrm{q}\left(R_{u}^{\gamma}\right) \text { and } \mathrm{q}^{\prime}\left(R_{u}^{\gamma}\right)>0
\end{aligned}
$$

That is: 


$$
\begin{aligned}
& \max _{m} V=[(1-\rho)+m \rho] R_{H}-(1-u) R_{f}-q u R_{f}+(1-q)\left(\rho(1-m)(1-u) R_{f}-[(1-\rho)+m \rho] u R_{u}^{\gamma}\right) \\
& -C(m) \\
& \text { with : } q=q\left(R_{u}^{\gamma}\right) \text { and } q^{\prime}\left(R_{u}^{\gamma}\right)>0
\end{aligned}
$$

The probability of being inspected is an increasing function of the subordinated debt rate of return which is a decreasing function of the level of monitoring.

The first order condition is:

$$
\begin{aligned}
& \rho R_{H}-(1-q)\left(\rho(1-u) R_{f}+\rho u R_{u}^{\gamma}+[(1-\rho)+m \rho] u\left(R_{u}^{\gamma}\right)_{m}^{\prime}\right) \\
& -q_{m}^{\prime}\left(u\left(R_{f}-[(1-\rho)+m \rho] R_{u}^{\gamma}\right)+\rho(1-m)(1-u) R_{f}\right)=C_{m}^{\prime}
\end{aligned}
$$

As the probability of being inspected is an increasing function of the subordinated debt rate of return, it is a decreasing function of the level of monitoring. A bank can decrease the probability of being inspected by increasing its monitoring.

Thus, if the bank holds subordinated debt, it has incentives to increase its monitoring if subordinated debt holders have sufficient incentives to assess bank's default risk; they must not perceive that they will be compensated if the bank defaults. In this case, they exercise direct market discipline which enables a decrease in the probability of default of the bank. If supervisors use the information contained in subordinated debt rate of return to assess bank's risk, inspections errors of safe banks no longer exist but this information can also misguide them; they can decide not to inspect a bank which is in reality risky. This case is all the more likely that the perception of a bail out in case of bank's default is high. Supervision errors are not necessarily lower when supervisors use market information to decide to early inspect or not a bank. However, using this information influences bank's behaviour because its inspection probability depends henceforth on its monitoring. 


\section{Conclusion}

One of the aims of mandatory subordinated debt is to enhance both direct and indirect market discipline. Direct market discipline is exercised via the rate of return of these liabilities which depends on bank's default risk. Indirect market discipline corresponds to the use of market signal by supervisors. In this model, we are between two on-site exams; supervisors cannot fully observe bank's risk of default but wish to assess it in order to decide if an early inspection is necessary. They can, in this context, use subordinated debt rate of return as a signal. If subordinated debt holders are able to assess bank's default risk and have sufficient incentives to exercise market discipline, mandatory subordinated debt give banks incentives to increase their monitoring and decrease their probability of default. Besides, if subordinated debt rate of return perfectly reflects bank's risk of default, supervisors no longer make errors in banks classification, supervisory resources are optimally allocated.

However, if subordinated debt holders cannot perfectly assess bank's default risk, the consequences of mandatory subordinated debt are ambiguous: if indirect market discipline enables a decrease in supervision errors, direct effects are not clear. Holding subordinated debt allows a decrease in bank's default risk only if market participants are sufficiently informed and able to assess it which implies that subordinated debt rate of return incorporates with sufficient accuracy bank's risk of default. If it is not the case, the bank can decide to decrease its moniotoring, which has only a small impact on the cost of its liabilities.

The incentives of subordinated debt holders also play a crucial role because if subordinated debt holders perceive strongly the possibility of a bail out if the bank fails, they do not incorporate bank's default risk into the rate of return they ask for. This can lead to an increase in risk. Besides, if supervisors use market information as a signal about bank's risk of default, it can in some cases increase classification errors and can lead to a less efficient allocation of supervisory resources.

Thus, if mandatory subordinated debt can enable a decrease in banks' risk exposure by enhancing market discipline and allow a better allocation of supervisory resources between two onsite exams, it is necessary beforehand to make sure that the conditions needed for market discipline to be effective are fulfilled. Subordinated debt holders must have abilities to assess banks' default risk, which implies that they have access to accurate and valuable information. The third pillar of Basel II by recommending increased financial transparency goes this way. However, it is also necessary that subordinated debt holders credibly perceive that they will not be compensated if the bank defaults. This implies, for example, that banks are not perceived as too big to fail. 
Appendix: Subordinated debt holders are perfectly informed about bank's default risk and have incentives to exercise market discipline.

We suppose here that subordinated debt holders are perfectly able to assess bank's default risk and that they have incentives to exercise market discipline as they are sure to not be compensated if the bank fails. Subordinated debt holders require an a-priori expected rate of return equal to the risk free rate of return ${ }^{11}$.

Their expected return is:

$$
E\left(R_{u}\right)=[(1-\rho)+m \rho] R_{u}^{P I}+\rho(1-m) 0
$$

Where $R_{u}^{P I}$ is the return obtained by subordinated debt holders if the bank does not fail.

As they require $\mathrm{E}\left(\mathrm{R}_{\mathrm{u}}\right)=\mathrm{R}_{\mathrm{f}}$, subordinated debt holders want to obtain a rate $R_{u}^{P I}$ so that:

$$
R_{u}^{P I}=\frac{R_{f}}{[(1-\rho)+m \rho]}
$$

$R_{u}^{P I}$ is an increasing function of the probability of default of the bank and a decreasing function of monitoring $(m)$.

The problem of the bank is:

$$
\begin{aligned}
& \max _{m} V=[(1-\rho)+m \rho]\left(R_{H}-(1-u) R_{f}-u R_{u}^{P I}\right)-q C C^{P I}-C(m) \\
& \text { with: } R_{u}^{P I}=\frac{R_{f}}{[(1-\rho)+m \rho]}
\end{aligned}
$$

The bank is inspected with probability q, which is independent of the level of monitoring chosen by the bank because supervisors cannot observe it between two on-site exams, and is subject to corrective actions. We suppose that when they are imposed bank's excessive risk taking disappears. Without them, the expected cost of debt, $u R_{f}+(1-\rho+m \rho)(1-u) R_{f}$, increases with monitoring. The cost $C C^{P I}$ is set such as the expected cost of debt and corrective actions is independent of the monitoring exercised by the bank:

$$
[(1-\rho)+m \rho]\left[(1-u) R_{f}\right]+C C^{I P}=(1-u) R_{f}
$$

\footnotetext{
${ }^{11}$ Blum [2002] and Calem and Rob [1999] also consider this hypothesis.
} 
Thus :

$$
C C^{I P}=\rho(1-m)(1-u) R_{f}
$$

The problem of the bank can be rewritten:

$$
\max _{m} V=[(1-\rho)+m \rho] R_{H}-R_{f}+(1-q) \rho(1-m)(1-u) R_{f}-C(m)
$$

The expected value of the bank is maximized when:

$$
\rho\left(R_{H}-(1-q)(1-u) R_{f}\right)=C_{m}^{\prime}
$$

Thus, we can notice, by comparing with equation (10) (fully insured debt and bank supervision) that the presence of subordinated debt enables an increase in the level of monitoring chosen by the bank and diminishes its default probability. Indeed, subordinated debt rate of return is a function of bank's default risk: for a portion $u$ of debt, the bank has no incentives to decrease its monitoring because an increase in default risk is fully reflected into the rate of return $R_{u}^{I P}$. In contrast to insured debt, the expected cost of this debt is not a increasing function of monitoring but is independent of it $\left(E\left(R_{u}\right)=[(1-\rho)+m \rho] R_{u}^{I P}=R_{f}\right)$. The greater is the portion $\mathrm{u}$ of subordinated debt, the closer we are from the socially optimal level of monitoring ${ }^{12}$.

\footnotetext{
${ }^{12}$ Here, if $\mathrm{u}=1$, we obtain the socially optimal situation. In reality, we can suppose that there are social costs when a bank fails which are taken into account by supervisors but not by the market which considers only private costs. In this case, even if the debt was fully constituted of subordinated debt, bank's monitoring would be less than the socially optimal level which indicates that market discipline cannot replace banking supervision. To simplify, here these private costs are not considered.
} 


\section{BIBLIOGRAPHY}

BERGER A.N., DAVIES S.M., FLANNERY M.J. (2000), "Comparing Market and Supervisory Assessments of Bank Performance: Who Knows What When?", Journal of Money, Credit and Banking, volume 32, pp 641-667

BLISS R. R., FLANNERY M. J., (2002), "Market discipline in the governance of US Bank Holding Companies: Monitoring versus influencing", European Finance Review 6, pp 361-395.

BLUM J.M., (2002), "Subordinated debt, market discipline, and banks' risk taking", Journal of Banking and Finance, vol 26, pp 1427-1441

BOARD OF GOVERNORS OF THE FEDERAL RESERVE SYSTEM (BGFRS), (1999), "Using subordinated debt as an instrument of market discipline", Staff Study, n¹72, December

BOOT A. W. A, GREENBAUM S., I., (1993), "Bank regulation, reputation and rents: theory and policy implications", in Capital Markets and Financial Intermediation

BOOT A. W. A., SCHMEITS A., (2000), "Market Discipline and Incentive Problems in Conglomerate Firms with Applications to Banking", Journal of Financial Intermediation, Vol 9, pp 240-273

CALEM P., ROB R., (1999), "The impact of capital based regulation on bank risk taking: a dynamic model", Journal of Financial Intermediation

COLE R. A., GUNTHER J. W., (1998), "Predicting bank failures: a comparison of on and off site monitoring systems", Journal of Financial Services Research, vol.13, pp 103-117

EVANOFF D. D., WALL L. D., (2000), "Subordinated Debt and Bank Capital Reform", in "Bank Fragility and regulation: evidence from different countries", edited by G. Kaufman, pp 53-119

GROPP R., VESALA J., (2004), "Deposit Insurance, Moral Hazard and Market Monitoring", European Central Bank Working Paper $\mathrm{n}^{\circ} 302$

GUNTHER J. W., MOORE R. R., (2003), "Loss underreporting and the auditing role of bank exams", Journal of Financial Intermediation, vol. 12, pp 153-177

LEVONIAN M., (2001), "Subordinated debt and the quality of market discipline in banking", Federal Reserve Bank of San Francisco

PARK S., (1997), "Risk taking behavior of banks under regulation", Journal of Banking and Finance, vol. 21, pp 491-507

PERSON M., BLAVARG M. The Use of Market Indicators in Financial Stability Analysis, Sveriges Riksbank Economic Review, 200 